\title{
CARBOXYLIC CATION EXCHANGE RESIN EFFECTS IN DOGS
}

\author{
By T. S. DANOWSKI, L. GREENMAN, F. M. MATEER, W. B. PARSONS, F. A. \\ WEIGAND, H. MERMELSTEIN, AND J. H. PETERS
}

\begin{abstract}
(From the Department of Research Medicine and the Renzichausen Foundation, University of Pittsburgh School of Medicine, Pittsburgh, Pa.)
\end{abstract}

(Submitted for publication April 23, 1951; accepted July 9, 1951)

Reports describing trials of exchange resins in removing cations from the gastrointestinal tract of experimental animals have been limited to toxicity studies and to measurements of the relative magnitudes of the oral intake and the stool output (1-3). In the experiments presented in this paper changes in serum, urine, and stool components, as well as the external and internal balances of certain electrolytes and of nitrogen have been determined in dogs receiving a carboxylic cation exchange resin in one of two forms. The chemical and physical characteristics of these agents have been described in detail in the introductory paper (4).

\section{MATERIALS AND METHODS}

Mongrel female dogs, maintained on a commercial feed ("Friskies") 1 and allowed free access to water, received a carboxylic cation exchange resin in the hydrogen or the sodium form for periods of seven to 11 days. In some instances beef extract or milk and sugar were used to enhance palatability, but many animals nonetheless lost weight partly or entirely as a consequence of anorexia induced by the regimens employed. Since this occurred to an equal degree when control and recovery periods of comparable length were alternated with resin periods it represented a common denominator in our experiments. The beginning and the end in each interval of the study were marked by catheterization of the urinary bladder, measurement of body weight and withdrawal of venous blood for analysis of blood nonprotein nitrogen (NPN) and sugar, and of serum carbon dioxide content, chloride, sodium, potassium, calcium, phosphorus and water, using previously described methods (5-7). The pH of anaerobic samples of serum was determined by means of the glass electrode. Food and resin intake, stool and urine output as well as any vomitus or rejected food were collected, measured, and analyzed separately for nitrogen, sodium, potassium and chloride content $(8-10)$. Stools were removed from the cage and weighed immediately. Procedures for partitioning the external balances into extracellular and cellular components have been described only in part in previous publications (11-17) and are therefore appended in detailed form.

1 Content per 100 g. : Na, 17.6 meq.; K, 10.2 meq.; Cl, 16.2 meq.; and N, $3.42 \mathrm{~g}$.
With but minor exceptions all findings have been subjected to conventional statistical analyses (18). In the case of the body weight and the serum constituents values observed at the end of each control, experimental, or recovery interval were subtracted from those present at the start of the particular period under scrutiny and expressed as increments or decrements $( \pm \Delta)$. After the means of these changes had been calculated (values greater than $2 \mathrm{~S}$. D. were discarded) the resin and post resin values were compared with those of the control periods. Changes were considered significantly different statistically when " $p$ " for the " $t$ " test was 0.05 or less. Urinary and stool output and the balance data were analyzed in terms of per diem values. The constituents of the stools have in addition been expressed in relation to stool mass as well as in terms of stool nitrogen. The data are presented in three tables; the statistical evaluation has been summarized in Table IV and in Figures 1 through 3 .

\section{RESULTS}

\section{Experiments with the carboxylic cation ex- changer in the hydrogen cycle}

A. Serum constituents: Table I and Figure 1 reveal that the administration of the hydrogen cycle resin produced a decrease in the serum sodium, carbon dioxide content or bicarbonate, and water concentrations, while the levels of chloride increased. The decrement of water was too small in magnitude, however, to account for the change in chloride. In some instances the change in carbon dioxide was accompanied by a fall in $\mathrm{pH}$. All of these alterations disappeared following withdrawal of the resin. The mean decrease in serum potassium during resin therapy and the subsequent changes during recovery were not significant.

$B$. Losses in stool: Ingestion of the cation exchanger in the hydrogen cycle was accompanied by increases in the excretion of sodium and potassium in feces without alteration in the losses of chloride and nitrogen (Table II and Figure 2). These observations, together with the failure to demonstrate any statistically significant increase in stool weight during resin ingestion even though 
TABLE I

Body weight and analyses of blood and serum in dogs receiving an exchange resin in the $H$ or the $N a$ cycle

\begin{tabular}{|c|c|c|c|c|c|c|c|c|c|c|c|c|c|c|}
\hline \multirow{2}{*}{\begin{tabular}{|c|} 
Subject \\
(Ace-Sox)
\end{tabular}} & \multirow{2}{*}{$\frac{\text { Ispe }}{\text { (deys) }}$} & \multicolumn{2}{|c|}{ Inerapy } & \multirow{2}{*}{$\frac{\text { Body Wgt. }}{\left(\mathrm{kg}_{\mathrm{H}}\right)}$} & \multicolumn{2}{|c|}{ Blood } & \multicolumn{8}{|c|}{ Serue } \\
\hline & & ${ }^{81}(6$ & a. $)^{\mathrm{Ma}}$ & & \begin{tabular}{|r|} 
Sugar \\
(agmot)
\end{tabular} & $\begin{array}{c}\text { NPN } \\
(\text { ngents) }\end{array}$ & $\begin{array}{r}\mathrm{HCO} \\
(\text { meq. } \\
\end{array}$ & 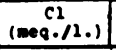 & $\begin{array}{c}\mathrm{Ma} \\
(\mathrm{meq} \cdot / 2 .)\end{array}$ & $\begin{array}{c}x \\
(n e q . / 2 .) \\
\end{array}$ & $C_{(\infty \pi)}$ & (P) & $\begin{array}{c}14,0 \\
(e . / 2 .)\end{array}$ & $\begin{array}{c}\text { Proteln } \\
(\text { coss) }\end{array}$ \\
\hline 2364 & $\begin{array}{r}0 \\
0-1 \\
1-7 \\
7-16 \\
14-21 \\
\end{array}$ & $\begin{array}{r}0 \\
0 \\
0 \\
0 \\
34\end{array}$ & $\begin{array}{l}0 \\
0 \\
0 \\
0 \\
0 \\
\end{array}$ & $\begin{array}{l}8.20 \\
0 \\
8.55 \\
8.70 \\
9.23\end{array}$ & $\begin{array}{c}80 \\
72 \\
70 \\
71 \\
\end{array}$ & $\begin{array}{l}41 \\
45 \\
41 \\
37 \\
42 \\
\end{array}$ & $\begin{array}{l}21.4 \\
21.8 \\
22.2 \\
14.0\end{array}$ & $\begin{array}{l}113.2 \\
108.0 \\
111.9 \\
108.4 . \\
121.3\end{array}$ & $\begin{array}{l}140 \\
156 \\
157 \\
154 \\
\end{array}$ & $\begin{array}{l}4.9 \\
4.6 \\
4.9 \\
5.8 \\
4.8 \\
\end{array}$ & $\begin{array}{c}11.9 \\
21.2 \\
0.8\end{array}$ & $\begin{array}{l}6.9 \\
7.0 \\
8.8 \\
7.1 \\
7.6\end{array}$ & $\begin{array}{l}935 \\
936 \\
943 \\
941 \\
947 \\
\end{array}$ & 5.95 \\
\hline $236 \mathrm{n}^{2}$ & $\begin{array}{r}0 \\
0-6 \\
6-13 \\
23-20 \\
20-27 \\
\end{array}$ & $\begin{array}{r}0 \\
0 \\
40 \\
0 \\
0 \\
\end{array}$ & $\begin{array}{r}0 \\
0 \\
0 \\
0 \\
40 \\
\end{array}$ & $\begin{array}{r}9.30 \\
10.10 \\
9.60 \\
9.68 \\
10.38 \\
\end{array}$ & $\begin{array}{l}70 \\
- \\
64 \\
74\end{array}$ & $\begin{array}{l}38 \\
36 \\
29 \\
32 \\
32 \\
\end{array}$ & $\begin{array}{l}23.8 \\
19.1 \\
16.0 \\
20.9 \\
22.1 \\
\end{array}$ & $\begin{array}{l}106.5 \\
211.0 \\
217.5 \\
214.7 \\
208.8 \\
\end{array}$ & $\begin{array}{l}258 \\
156 \\
160 \\
160 \\
257 \\
\end{array}$ & & $\begin{array}{r}0.3 \\
0.0 \\
9.4\end{array}$ & $\begin{array}{l}6.4 \\
6.6 \\
6.8 \\
6.2 \\
7.2 \\
\end{array}$ & $\begin{array}{l}901 \\
938 \\
936 \\
936 \\
938\end{array}$ & \\
\hline 2438 & $\begin{array}{r}0 \\
0-1 \\
1-7 \\
7-14 \\
14-21 \\
\end{array}$ & $\begin{array}{r}0 \\
0 \\
0 \\
40 \\
0 \\
\end{array}$ & $\begin{array}{l}0 \\
0 \\
0 \\
0 \\
0 \\
\end{array}$ & $\begin{array}{r}9.48 \\
9.68 \\
7.95 \\
9.18 \\
\end{array}$ & $\begin{array}{l}85 \\
81 \\
86 \\
88 \\
\end{array}$ & $\begin{array}{l}32 \\
- \\
29 \\
79 \\
31\end{array}$ & $\begin{array}{l}21.6 \\
22.2 \\
21.5 \\
14.0 \\
23.4 \\
\end{array}$ & $\begin{array}{r}108.8 \\
103.3 \\
109.4 \\
93.2 \\
211.3 \\
\end{array}$ & $\begin{array}{c}145 \\
158 \\
156 \\
- \\
- \\
\end{array}$ & $\begin{array}{l}5.2 \\
4.6 \\
4.7 \\
4.3 \\
4.7 \\
\end{array}$ & $\begin{array}{c}12.9 \\
10.5 \\
8.6\end{array}$ & $\begin{array}{l}5.2 \\
3.8 \\
5.6 \\
3.9 \\
4.6 \\
\end{array}$ & $\begin{array}{l}920 \\
925 \\
923 \\
809 \\
927\end{array}$ & 7.03 \\
\hline $243 B^{2}$ & $\begin{array}{r}0 \\
0-6 \\
6-13 \\
23-20 \\
20-21 \\
\end{array}$ & $\begin{array}{r}0 \\
0 \\
34 \\
0 \\
0 \\
\end{array}$ & $\begin{array}{r}0 \\
0 \\
0 \\
0 \\
40 \\
\end{array}$ & $\begin{array}{r}9.60 \\
10.00 \\
9.48 \\
10.18 \\
10.62 \\
\end{array}$ & $\begin{array}{l}64 \\
- \\
66 \\
72\end{array}$ & $\begin{array}{l}32 \\
32 \\
25 \\
33 \\
30 \\
\end{array}$ & $\begin{array}{l}20.4 \\
16.7 \\
21.8 \\
22.9 \\
24.5 \\
\end{array}$ & $\begin{array}{l}109.2 \\
107.0 \\
113.7 \\
211.3 \\
108.3\end{array}$ & $\begin{array}{c}156 \\
- \\
156 \\
156 \\
\end{array}$ & $\begin{array}{l}5.8 \\
4.2 \\
4.5 \\
4.8 \\
5.7 \\
\end{array}$ & $\begin{array}{c}\text { i. } \\
\vdots \\
2.0\end{array}$ & $\begin{array}{l}4.5 \\
4.8 \\
3.8 \\
4.9 \\
5.2 \\
\end{array}$ & $\begin{array}{l}931 \\
915 \\
- \\
925 \\
929\end{array}$ & \\
\hline $246 C$ & $\begin{array}{r}0 \\
0-1 \\
1-7 \\
7-14 \\
14-21 \\
\end{array}$ & $\begin{array}{l}0 \\
0 \\
0 \\
0 \\
0 \\
\end{array}$ & $\begin{array}{l}0 \\
0 \\
0 \\
0 \\
0 \\
\end{array}$ & $\begin{array}{c}6.00 \\
6.00 \\
5.60 \\
5.63\end{array}$ & $\begin{array}{l}94 \\
66 \\
79 \\
68 \\
76 \\
\end{array}$ & $\begin{array}{l}35 \\
34 \\
28 \\
29 \\
35 \\
\end{array}$ & $\begin{array}{l}17.0 \\
20.8 \\
21.2 \\
22.7 \\
19.7\end{array}$ & $\begin{array}{l}216.8 \\
213.5 \\
212.4 \\
113.2 \\
214.5\end{array}$ & $\begin{array}{c}154 \\
164 \\
159 \\
- \\
152\end{array}$ & $\begin{array}{l}4.7 \\
3.9 \\
4.6 \\
5.4 \\
4.9\end{array}$ & $\begin{array}{c}- \\
21.2 \\
21.4 \\
22.2\end{array}$ & $\begin{array}{l}4.2 \\
4.4 \\
3.7 \\
4.6 \\
4.4 \\
\end{array}$ & $\begin{array}{c}933 \\
936 \\
934 \\
919 \\
\end{array}$ & 6.74 \\
\hline 2470 & $\begin{array}{r}0 \\
0-1 \\
1-7 \\
7-14 \\
14-21\end{array}$ & $\begin{array}{r}0 \\
0 \\
0 \\
40 \\
0\end{array}$ & $\begin{array}{l}0 \\
0 \\
0 \\
0 \\
0 \\
\end{array}$ & $\begin{array}{c}8.82 \\
-. \\
8.98 \\
9.15 \\
9.53\end{array}$ & $\begin{array}{l}73 \\
61 \\
68 \\
65 \\
67 \\
\end{array}$ & $\begin{array}{l}32 \\
29 \\
31 \\
33 \\
30 \\
\end{array}$ & $\begin{array}{l}20.0 \\
22.4 \\
23.4 \\
17.4 \\
22.9\end{array}$ & $\begin{array}{l}212.4 \\
108.7 \\
113.5 \\
118.0 \\
122.6\end{array}$ & $\begin{array}{c}143 \\
157 \\
156 \\
- \\
256\end{array}$ & $\begin{array}{l}4.9 \\
4.6 \\
4.8 \\
4.7 \\
4.9\end{array}$ & $\begin{array}{c}- \\
10.3 \\
10.2 \\
- \\
9.8\end{array}$ & $\begin{array}{l}5.1 \\
5.0 \\
4.8 \\
4.4 \\
4.0\end{array}$ & $\begin{array}{c}943 \\
- \\
945 \\
932\end{array}$ & 4.35 \\
\hline $247 D^{2}$ & $\begin{array}{r}0 \\
0-6 \\
6-13 \\
13-20 \\
20-27 \\
\end{array}$ & $\begin{array}{r}0 \\
0 \\
40 \\
0 \\
0 \\
\end{array}$ & $\begin{array}{r}0 \\
0 \\
0 \\
0 \\
40 \\
\end{array}$ & $\begin{array}{r}9.15 \\
9.20 \\
9.30 \\
9.38 \\
10.00 \\
\end{array}$ & $\begin{array}{l}- \\
61 \\
72\end{array}$ & $\begin{array}{l}29 \\
30 \\
29 \\
32 \\
31 \\
\end{array}$ & $\begin{array}{c}21.8 \\
22.3 \\
- \\
23.7 \\
25.0 \\
\end{array}$ & $\begin{array}{l}113.0 \\
110.5 \\
119.2 \\
112.8 \\
107.2\end{array}$ & $\begin{array}{l}145 \\
161 \\
157 \\
159 \\
156 \\
\end{array}$ & $\begin{array}{r}4.3 \\
4.7 \\
-.7 \\
4.7 \\
5.0 \\
\end{array}$ & $\begin{array}{r}9.7 \\
10.9 \\
9.5 \\
8.3 \\
\end{array}$ & $\begin{array}{l}4.3 \\
4.2 \\
3.7 \\
3.8 \\
4.0 \\
\end{array}$ & $\begin{array}{l}917 \\
936 \\
942 \\
936 \\
940 \\
\end{array}$ & \\
\hline $188 z$ & $\begin{array}{r}0 \\
0-5 \\
5-12 \\
12-19 \\
19-26 \\
\end{array}$ & $\begin{array}{r}0 \\
0 \\
40 \\
0 \\
0 \\
\end{array}$ & $\begin{array}{r}0 \\
0 \\
0 \\
0 \\
10 \\
\end{array}$ & $\begin{array}{l}17.55 \\
17.58 \\
17.73 \\
18.03 \\
18.28 \\
\end{array}$ & $\begin{array}{r}- \\
- \\
75 \\
79\end{array}$ & $\begin{array}{l}46 \\
34 \\
27 \\
32 \\
34 \\
\end{array}$ & $\begin{array}{l}21.7 \\
20.1 \\
20.2 \\
20.7 \\
22.4\end{array}$ & $\begin{array}{l}113.3 \\
111.6 \\
113.0 \\
112.6 \\
110.8\end{array}$ & $\begin{array}{l}142 \\
162 \\
156 \\
156 \\
160 \\
\end{array}$ & $\begin{array}{l}5.4 \\
4.8 \\
4.5 \\
5.0 \\
4.6 \\
\end{array}$ & $\begin{array}{l}- \\
10.1 \\
11.6 \\
11.6 \\
11.1\end{array}$ & $\begin{array}{l}5.0 \\
4.8 \\
4.0 \\
3.7 \\
4.8 \\
\end{array}$ & $\begin{array}{l}951 \\
937 \\
942 \\
938 \\
940\end{array}$ & \\
\hline 190 & $\begin{array}{r}0 \\
0-10 \\
10-15 \\
\end{array}$ & $\begin{array}{l}0 \\
0 \\
0 \\
\end{array}$ & $\begin{array}{l}0 \\
0 \\
0 \\
\end{array}$ & $\begin{array}{r}10.66 \\
10.33 \\
9.54 \\
\end{array}$ & : & $\begin{array}{l}32 \\
27 \\
26 \\
\end{array}$ & $\begin{array}{l}22.4 \\
22.9 \\
18.4 \\
\end{array}$ & $\begin{array}{l}213.6 \\
211.4 \\
211.0 \\
\end{array}$ & $\begin{array}{l}152 \\
155 \\
248 \\
\end{array}$ & $\begin{array}{l}4.3 \\
4.6 \\
3.9 \\
\end{array}$ & $\begin{array}{c}10.3 \\
10.2 \\
- \\
\end{array}$ & $\begin{array}{r}1.7 \\
2.2 \\
- \\
\end{array}$ & $\begin{array}{l}937 \\
933 \\
937 \\
\end{array}$ & \\
\hline 246 & $\begin{array}{r}0 \\
0-10 \\
10-15 \\
\end{array}$ & $\begin{array}{l}0 \\
0 \\
0 \\
\end{array}$ & $\begin{array}{l}0 \\
0 \\
0 \\
\end{array}$ & $\begin{array}{l}6.10 \\
5.84 \\
5.42 \\
\end{array}$ & - & $\begin{array}{l}33 \\
30 \\
34 \\
\end{array}$ & $\begin{array}{l}19.5 \\
19.5 \\
22.4 \\
\end{array}$ & $\begin{array}{l}113.8 \\
117.3 \\
102.2 \\
\end{array}$ & $\begin{array}{l}149 \\
162 \\
133 \\
\end{array}$ & $\begin{array}{l}4.7 \\
4.7 \\
4.0 \\
\end{array}$ & $\begin{array}{c}21.2 \\
21.4 \\
-\end{array}$ & $\begin{array}{r}2.3 \\
2.6 \\
- \\
\end{array}$ & $\begin{array}{c}930 \\
- \\
932\end{array}$ & \\
\hline 75515 & $\begin{array}{r}0 \\
0-10 \\
10-15 \\
\end{array}$ & $\begin{array}{l}0 \\
0 \\
0 \\
\end{array}$ & $\begin{array}{l}0 \\
0 \\
0 \\
\end{array}$ & $\begin{array}{l}19.02 \\
18.74 \\
18.12 \\
\end{array}$ & - & $\begin{array}{l}32 \\
27 \\
27 \\
\end{array}$ & $\begin{array}{l}19.9 \\
20.9 \\
18.4 \\
\end{array}$ & $\begin{array}{l}112.4 \\
210.6 \\
104.7\end{array}$ & $\begin{array}{l}156 \\
160 \\
138 \\
\end{array}$ & $\begin{array}{l}4.2 \\
4.3 \\
3.2 \\
\end{array}$ & $\begin{array}{c}11.0 \\
10.8 \\
.\end{array}$ & $\begin{array}{c}1.5 \\
1.8 \\
- \\
\end{array}$ & $\begin{array}{l}931 \\
923 \\
935 \\
\end{array}$ & \\
\hline 92516 & $\begin{array}{r}0 \\
0-10 \\
20-18 \\
\end{array}$ & $\begin{array}{r}0 \\
0 \\
60 \\
\end{array}$ & $\begin{array}{l}0 \\
0 \\
0 \\
\end{array}$ & $\begin{array}{l}15.24 \\
15.01 \\
24.29 \\
\end{array}$ & $\ddot{-}$ & $\begin{array}{l}25 \\
32 \\
35\end{array}$ & $\begin{array}{l}22.9 \\
22.5 \\
13.8 \\
\end{array}$ & $\begin{array}{l}210.3 \\
108.9 \\
215.6 \\
\end{array}$ & $\begin{array}{l}150 \\
146 \\
243 \\
\end{array}$ & $\begin{array}{l}4.1 \\
4.5 \\
4.2 \\
\end{array}$ & $\begin{array}{c}10.7 \\
10.5 \\
-\end{array}$ & $\begin{array}{c}2.7 \\
2.2 \\
- \\
\end{array}$ & $\begin{array}{c}932 \\
921 \\
- \\
\end{array}$ & \\
\hline 382 & $\begin{array}{r}0 \\
0-21 \\
21-20 \\
20-30 \\
30-41 \\
41-48 \\
\end{array}$ & $\begin{array}{l}0 \\
42 \\
0 \\
0 \\
0 \\
0\end{array}$ & $\begin{array}{r}0 \\
0 \\
0 \\
30 \\
0 \\
0 \\
\end{array}$ & $\begin{array}{l}11.85 \\
11.25 \\
11.02 \\
10.73 \\
10.32 \\
10.24 \\
\end{array}$ & $\begin{array}{l}- \\
- \\
- \\
- \\
\end{array}$ & $\begin{array}{l}34 \\
25 \\
31 \\
26 \\
27 \\
32 \\
\end{array}$ & $\begin{array}{l}20.6 \\
19.4 \\
21.4 \\
22.3 \\
22.6 \\
19.4\end{array}$ & $\begin{array}{l}210.5 \\
215.6 \\
114.4 \\
101.1 \\
109.4 \\
212.3\end{array}$ & $\begin{array}{l}145 \\
149 \\
241 \\
154 \\
148 \\
148 \\
\end{array}$ & 4.8 & $\begin{array}{c}9.5 \\
0 \\
10.0 \\
10.3 \\
21.6\end{array}$ & $\begin{array}{c}2.5 \\
-. \\
2.7 \\
3.4 \\
- \\
\end{array}$ & $\begin{array}{l}924 \\
936 \\
928 \\
932 \\
932 \\
\end{array}$ & \\
\hline 391 & $\begin{array}{r}0 \\
0-11 \\
11-20 \\
20-30 \\
30-41 \\
42-48 \\
\end{array}$ & $\begin{array}{r}0 \\
33 \\
0 \\
0 \\
0 \\
0 \\
\end{array}$ & $\begin{array}{r}0 \\
0 \\
0 \\
30 \\
0 \\
0 \\
\end{array}$ & $\begin{array}{l}9.93 \\
8.20 \\
8.53 \\
8.26 \\
7.88 \\
7.66 \\
\end{array}$ & 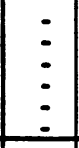 & $\begin{array}{l}29 \\
31 \\
31 \\
28 \\
32 \\
30\end{array}$ & $\begin{array}{r}20.1 \\
9.7 \\
20.3 \\
23.0 \\
20.6 \\
20.1 \\
\end{array}$ & $\begin{array}{l}212.3 \\
217.4 \\
214.6 \\
212.9 \\
213.5 \\
213.4\end{array}$ & $\begin{array}{l}250 \\
248 \\
253 \\
252 \\
243 \\
253\end{array}$ & $\begin{array}{r}4.6 \\
4.3 \\
\end{array}$ & $\begin{array}{l}9.2 \\
0.7 \\
9.8 \\
9.8 \\
9.9\end{array}$ & $\begin{array}{l}5.4 \\
2.4 \\
3.0 \\
2.6 \\
\end{array}$ & $\begin{array}{l}934 \\
951 \\
944 \\
942 \\
940 \\
942 \\
\end{array}$ & \\
\hline 404 & $\begin{array}{r}0 \\
0-21 \\
21-20 \\
-20-30 \\
30-41 \\
41-48\end{array}$ & $\begin{array}{r}0 \\
35 \\
0 \\
0 \\
0 \\
0 \\
\end{array}$ & $\begin{array}{r}0 \\
0 \\
0 \\
30 \\
0 \\
0 \\
\end{array}$ & $\begin{array}{l}9.65 \\
8.50 \\
8.25 \\
8.09 \\
7.80 \\
7.62\end{array}$ & 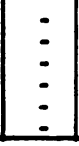 & $\begin{array}{l}25 \\
29 \\
28 \\
28 \\
30 \\
30\end{array}$ & $\begin{array}{l}21.6 \\
17.0 \\
23.4 \\
22.7 \\
20.3 \\
25.3\end{array}$ & $\begin{array}{r}105.7 \\
217.5 \\
97.0 \\
212.1 \\
212.9 \\
208.6 \\
\end{array}$ & $\begin{array}{l}240 \\
252 \\
242 \\
255 \\
143 \\
153\end{array}$ & & $\begin{array}{c}20.2 \\
-5.0 \\
21.0 \\
21.5 \\
21.2\end{array}$ & $\begin{array}{l}1.4 \\
6.0\end{array}$ & $\begin{array}{c}\text { 9i2 } \\
933 \\
946 \\
\text { 94h } \\
- \\
\end{array}$ & \\
\hline
\end{tabular}


the mean values did increase, indicate that the changes described above were not related to increased stool mass. Following withdrawal of the resin, the excretion of sodium and potassium returned to levels characteristic of the control periods.

C. Losses in urine: The average daily urine volumes rose during hydrogen cycle resin treatment without loss of body weight (Table II), pointing to increased exchanges of water. From the data available it is not possible to decide whether this change in urine volume was a manifestation or a cause of a greater intake of water. Concomitantly it was noted that the mean levels of sodium and of potassium in urine decreased on resin therapy, together with a diminution in the total daily excretion of these electrolytes (Figure 2). The first of these changes can be ascribed, at least in part, to the increased urine volumes, but the second suggests a diminished excretion of sodium and potassium in urine reciprocal to the increased losses of these electrolytes in stools described earlier. This possibility is supported by the observation that the resin did not alter the output of chloride and nitrogen in stools and that the urinary chloride and

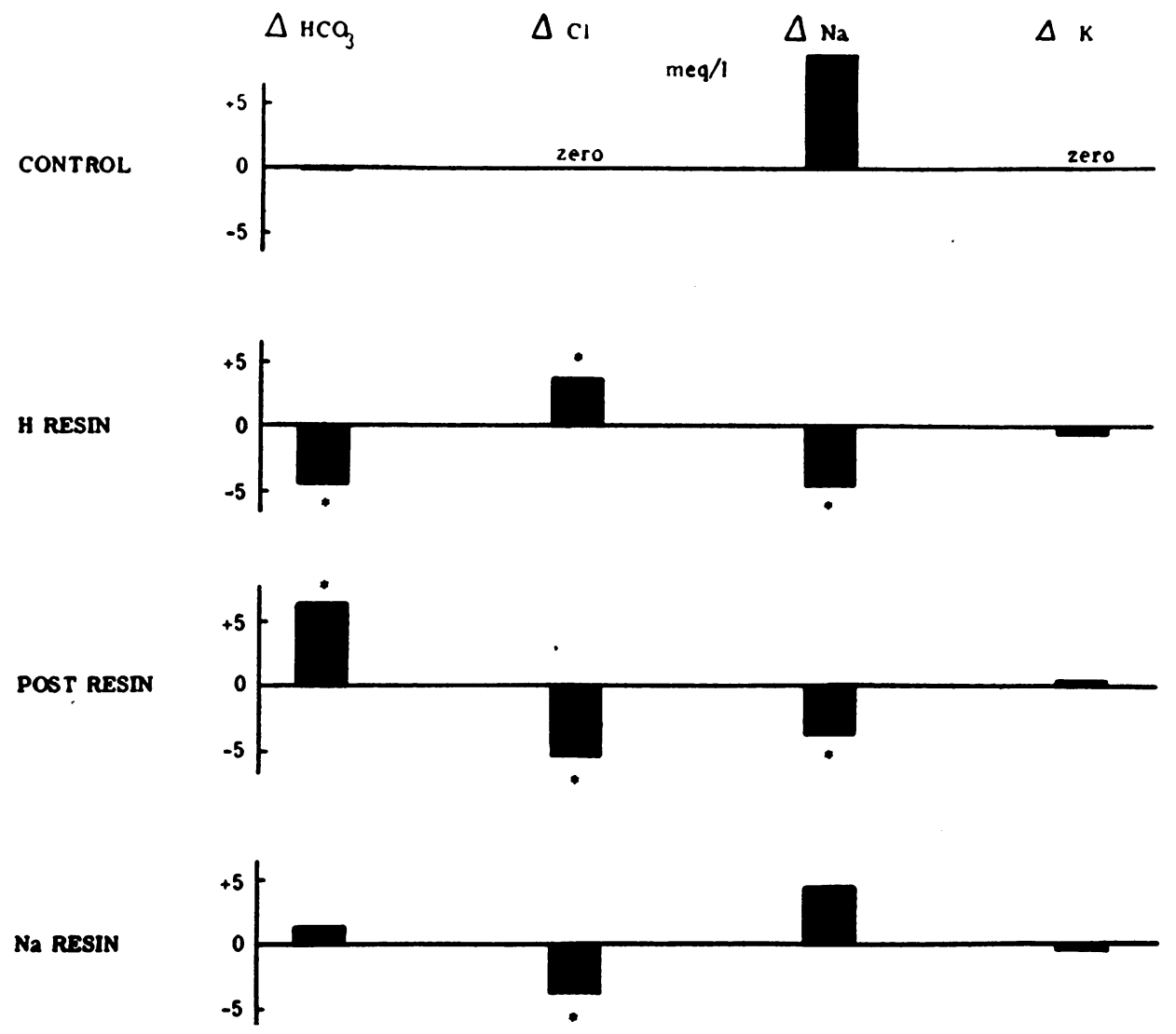

Fig. 1. Alterations in Serum Constituents

Mean changes in serum constituents between the onset and the end of the indicated experimental periods are depicted in terms of milli-equivalents per liter. Asterisks identify statistically significant differences ("p" values of 0.05 or less) upon comparison with the changes in the control periods. The statistical summary (Table IV) contains the actual values employed in setting up Figures 1, 2, and 3 of this paper. During $\mathrm{H}$ resin ingestion the serum bicarbonate decreased with a subsequent return to control levels during the post resin period. Similarly, the hyperchloremia present at the end of $\mathrm{H}$ resin therapy disappeared in the recovery interval. Relative hyponatremia which appeared in the $\mathbf{H}$ resin period persisted into the post resin interval. The sodium form of the exchanger lowered serum chloride. Serum potassium remained relatively constant throughout all studies. Though not presented above, the same was true of serum calcium, phosphorus and protein while the mean serum water increased by $0.006 \mathrm{~g} . / 1$. 
TABLE II

Intake data and urine and stool output in dogs receiving an exchange resin in the $\mathrm{H}$ or the $\mathrm{Na}$ cycle

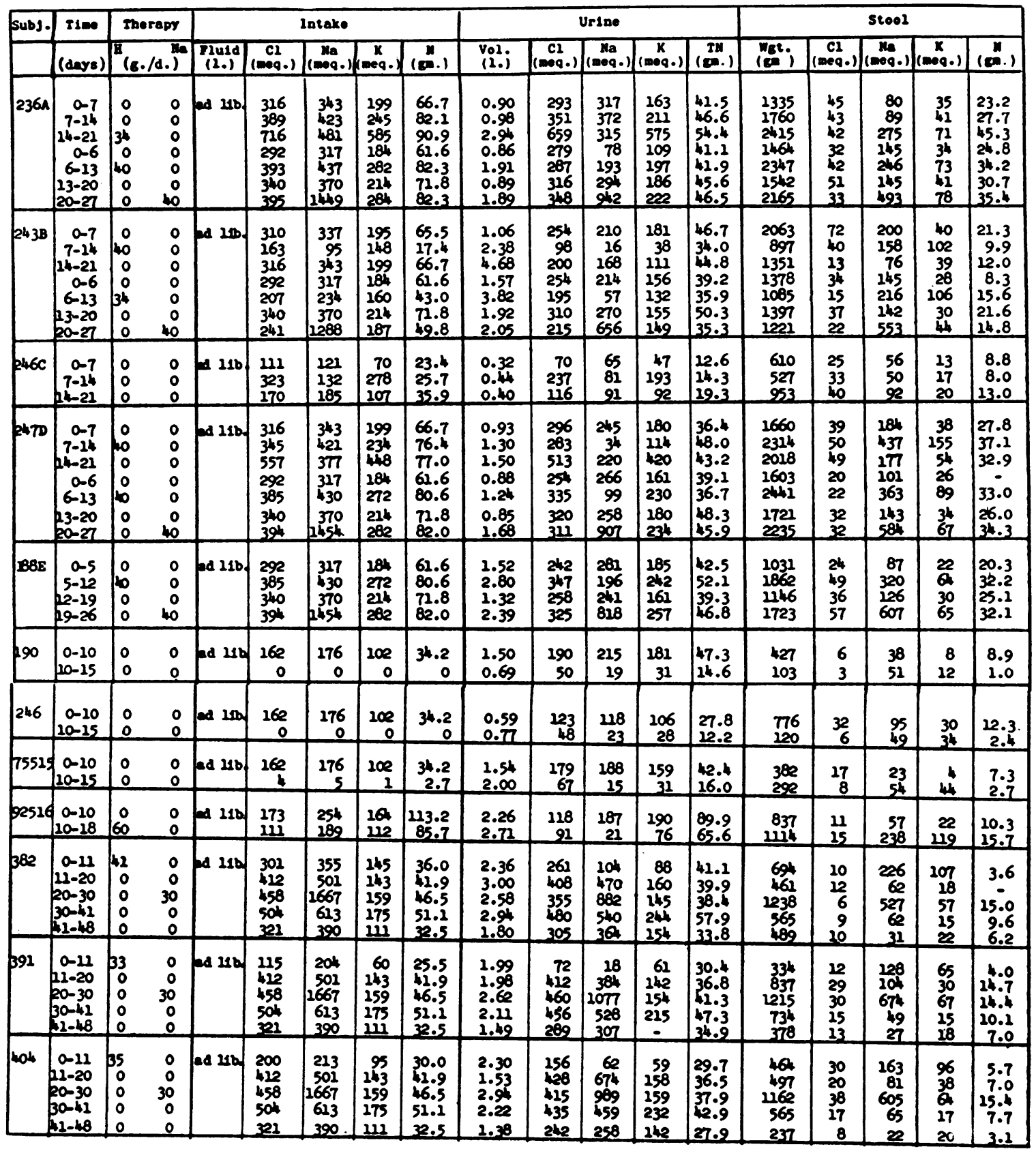

nitrogen merely decreased in concentration but not in the total amount lost per unit of time. In the periods following resin the volume and composition of urine returned to values indistinguishable from controls.

D. Balance data: Subtraction of the electrolytes and nitrogen lost in stools, urine and occasionally in vomitus from the respective intake of these constituents in food revealed that during the administration of the hydrogen cycle resin the losses of potassium from the body were increased without any statistically significant change in the balances of chloride, sodium or nitrogen (Table III and Figure 3). The negative values characteristic of 


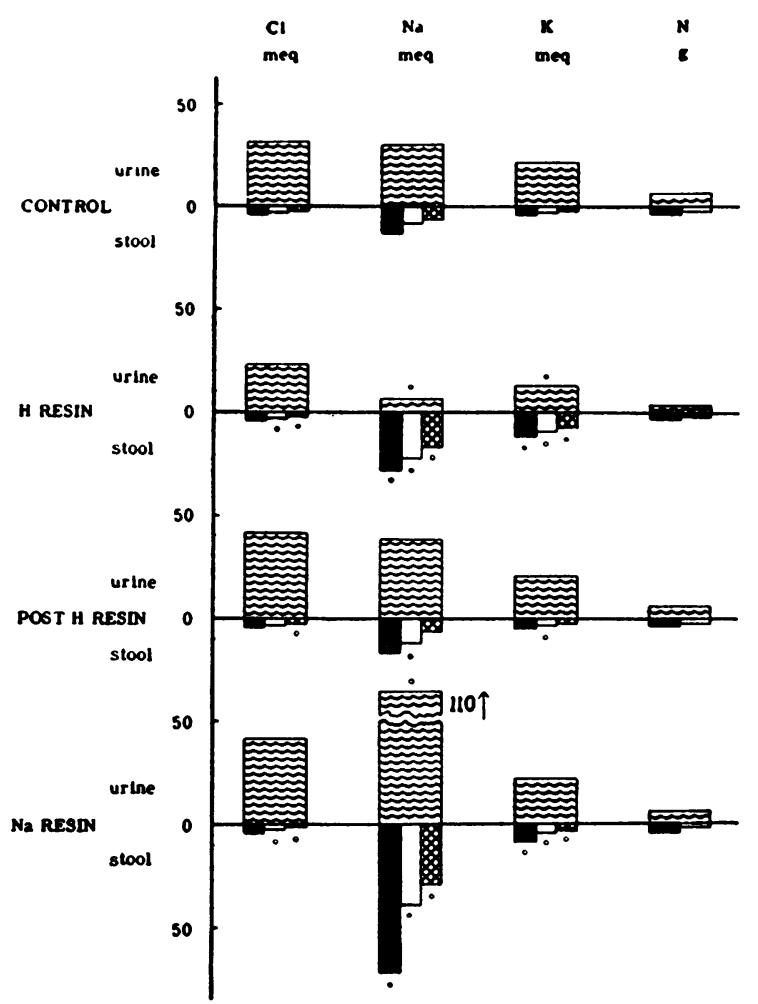

Fig. 2. Daily Excretions of Electrolytes and of Nitrogen in Urine and in Stools-Presented as Mean VALUES

Columns with horizontal waves depict daily urinary excretion of the constituent. The smaller columns below the horizontal lines are based on stool data. Black columns refer to per day values, open columns indicate excretion per $100 \mathrm{~g}$. of stool and the crosshatching identifies the electrolyte: nitrogen ratio. The small circles indicate that the change in the mean from the control is statistically significant.

Ingestion of the $\mathrm{H}$ form of the resin increased the stool excretion of potassium and of sodium above control values. This was accompanied by decreased urinary output of these electrolytes. The sodium form of the resin also raised the stool potassium and sodium. Urinary potassium in these experiments, however, did not decrease below control values; urinary sodium on the other hand rose markedly. The changes in stool chloride were present only irregularly and were of small magnitude, and no significant alterations occurred in urine chloride. Nitrogen excretion was not altered.

the control periods reflect the anorexia and weight loss cited earlier.

Partitioning of the balances into extracellular and cellular phases reveals that the observed negative values for potassium represent losses of this electrolyte from cells. Further, corrections for the anabolism or catabolism of protein indicate that these negative balances represent losses of cell potassium with, as well as in excess of, nitrogen. The mean change in extracellular sodium was of insufficient magnitude to result in an increased negative external balance. They do indicate, however, that under the aforementioned experimental conditions, the hydrogen form resin can remove sodium from the chloride space as well as lower the serum sodium levels.

\section{Experiments with the carboxylic cation ex- changer in the sodium cycle}

$A$. Serum constituents: In contrast to the hydrogen form of the resin, the exchanger charged with sodium did not produce acidosis, hyperchloremia nor hyponatremia (Table I and Figure 1). A mean decrement of -3.6 meq. $/ 1$. did occur in the serum chloride concentration.

$B$. Losses in stool: The effects of the sodium cycle resin on stool constituents were qualitatively similar to those observed during hydrogen resin therapy (Figure 2). As might be expected from the greater intake of sodium in using the exchanger in the sodium cycle, this cation appeared in much greater amounts in the stool. At the same time there occurred an approximately two-fold increase in the amount of potassium excreted each day in contrast to the three-fold rise observed in the hydrogen resin studies. Stool mass, stool chloride and stool nitrogen did not vary significantly from the control values.

C. Losses in urine: Ingestion of the carboxylic cation exchanger in the sodium cycle was associated with increases in urine volume (Table II) and decreases in urine potassium and nitrogen concentration quite comparable to those recorded in the hydrogen resin experiments (Figure 2). On the other hand, in contrast to the results in the first group of studies, the animals receiving the sodium cycle resin showed an increase in the daily urinary sodium output. These reflected of course absorption and subsequent urinary excretion of sodium released from the sodium form of the resin. Finally, it should be pointed out that the doubled output of potassium via the gastrointestinal tract was not accompanied by a compensatory fall in the uri- 
TABLE III

External, extracellular, and cell balances in dogs receiving an exchange resin in the $H$ or the $\mathrm{Na}$ cycle

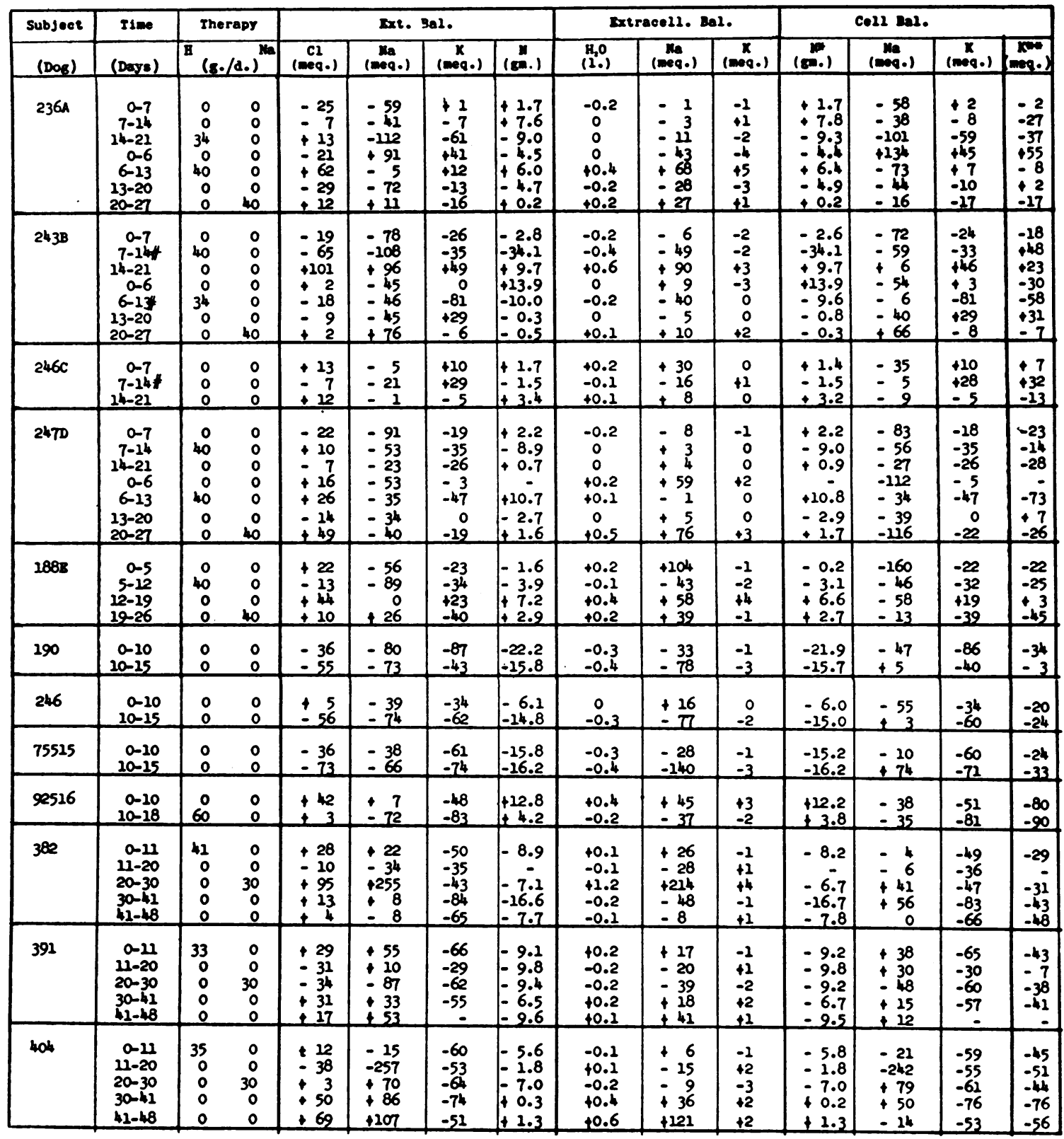

* Corrected for balance of NPN

** In excess of anabolism and catabolism of protein

External balances have been corrected for losses in vomitus

nary losses of this electrolyte. This differs of course from the hydrogen cycle resin studies in which reciprocal relationships could be postulated following a greater, i.e., a three-fold rise in the amounts of potassium lost in stools.
D. Balance data: A significant proportion of the sodium released from the carboxylic cation exchanger and then absorbed was retained within the body despite the increases in urinary output described above. The data in Table III and Fig- 
ure 3 indicate that this was associated, in contrast to the findings in the hydrogen resin studies, with an expansion of the chloride space.

\section{DISCUSSION}

Hydrogen resin therapy in dogs lowered serum sodium levels and raised the concentrations of serum chloride. The latter change is reminiscent of a similar response induced by acidifying diuretics
$(19,20)$. The hyperchloremia was presumably initiated by the absorption of hydrogen ions set free from the resin with subsequent excretion in urine with anions other than chloride. The decrease in serum bicarbonate in these studies as a group represents, therefore, a metabolic acidosis and is attributable in a varying degree to a combination of hyperchloremia and a slight fall in fixed base. The lowered $\mathrm{pH}$ values support this view

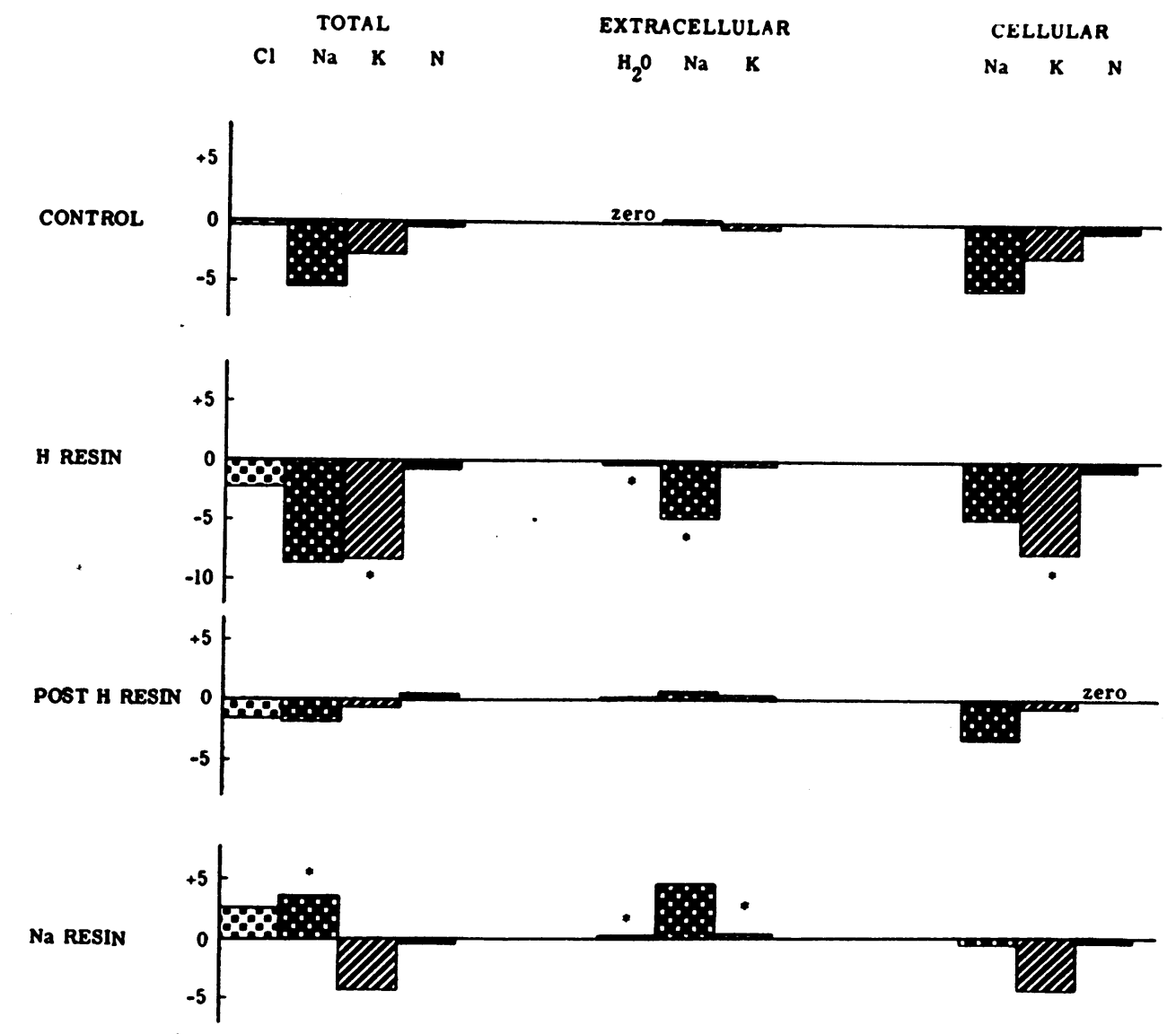

Fig. 3. Average Daily Balances

The columns represent mean daily total (external), extracellular, and intracellular balances of chloride, sodium, and potassium in milli-equivalents and of nitrogen in grams during the indicated therapy. To observe the resin effects compare the balances during their administration to those during the control period. Asterisks denote mean values significantly different statistically from those characteristic of the control studies. Significant changes during $\mathrm{H}$ resin ingestion consisted of an approximately three-fold increase in the negative total balance of potassium. This cation was lost from the intracellular space both with and in excess of nitrogen since the cellular potassium represented has been corrected for the metabolism of protein. Sodium and water were lost from the extracellular or chloride space in the proportions in which they are usually present in this compartment. Balances during the post $\mathrm{H}$ resin period were similar to the control interval. The negative balances during both regimens reflect the inadequate dietary intake of the animals. Comparable diets were eaten, however, during all periods. In the $\mathrm{Na}$ resin studies exogenous sodium was retained in the expanded extracellular space and potassium increased slightly in this same compartment. 
TABLE IV

Statistical evaluation of resin data

\begin{tabular}{|c|c|c|c|c|c|c|c|c|c|c|c|c|c|c|}
\hline & & & \multicolumn{3}{|c|}{ Control periods } & \multicolumn{3}{|c|}{$H$ resin periods } & \multicolumn{3}{|c|}{ Post $\mathrm{H}$ resin periods } & \multicolumn{3}{|c|}{ Na resin periods } \\
\hline & & & Mean & No. & S. D. & Mean & No. & S. D. & Mean & No. & S. D. & Mean & No. & S. D. \\
\hline$\Delta$ Serum & $\begin{array}{l}\mathrm{HCO} \\
\mathrm{Cl} \\
\mathrm{Na} \\
\mathrm{K} \\
\mathrm{H}_{2} \mathrm{O}\end{array}$ & $\begin{array}{l}\text { meq. } \\
\text { meq. } \\
\text { meq. } \\
\text { meq. } \\
\text { l. }\end{array}$ & $\begin{array}{c}-0.1 \\
0.0 \\
+8.8 \\
0.0 \\
-0.001\end{array}$ & \begin{tabular}{l|}
22 \\
22 \\
19 \\
22 \\
17
\end{tabular} & $\begin{array}{l}2.3 \\
2.6 \\
6.9 \\
0.7 \\
0.009\end{array}$ & $\begin{array}{l}-4.4< \\
+3.7> \\
-4.5< \\
-0.4 \\
+0.006>\end{array}$ & $\begin{array}{l}13 \\
13 \\
11 \\
12 \\
10\end{array}$ & $\begin{array}{c}3.8 \\
7.5 \\
11.7 \\
0.3 \\
0.007\end{array}$ & $\begin{array}{c}+6.3> \\
-5.2< \\
-3.7< \\
+0.4 \\
0.000\end{array}$ & $\begin{array}{l}8 \\
8 \\
6 \\
8 \\
7\end{array}$ & $\begin{array}{l}3.9 \\
6.5 \\
5.2 \\
0.7 \\
0.015\end{array}$ & $\begin{array}{l}+1.2 \\
-3.6< \\
+4.3 \\
-0.2 \\
+0.002\end{array}$ & \begin{tabular}{l|}
7 \\
6 \\
6 \\
7 \\
7
\end{tabular} & $\begin{array}{l}1.3 \\
1.8 \\
7.1 \\
0.6 \\
0.003\end{array}$ \\
\hline Stool & \begin{tabular}{|lr} 
wgt. & \\
$\mathrm{Cl}$ & \\
$\mathrm{Cl}$ & $\mathrm{m}$ \\
$\mathrm{Cl}$ & $\mathrm{mec}$ \\
$\mathrm{Na}$ & \\
$\mathrm{Na}$ & $\mathrm{m}$ \\
$\mathrm{Na}$ & $\mathrm{mec}$ \\
$\mathbf{K}$ & \\
$\mathbf{K}$ & $\mathrm{m}$ \\
$\mathbf{K}$ & $\mathrm{mec}$ \\
$\mathbf{N}$ & \\
$\mathrm{N}$ &
\end{tabular} & $\begin{array}{r}\mathrm{g} . / \mathrm{d} . \\
\mathrm{meq} / \mathrm{d} . \\
\mathrm{q} . / 100 \mathrm{~g} . \\
1.0 \mathrm{~g} . \mathrm{N} \\
\mathrm{meq} / \mathrm{d} . \\
\mathrm{q} . / 100 \mathrm{~g} . \\
1.0 \mathrm{~g} . \mathrm{N} \\
\mathrm{meq} . / \mathrm{d} . \\
\mathrm{q} . / 100 \mathrm{~g} . \\
1.0 \mathrm{~g} . \mathrm{N} \\
\mathrm{g} . / \mathrm{d} . \\
\mathrm{g} . / 100 \mathrm{~g} .\end{array}$ & $\begin{array}{r}145.5 \\
3.7 \\
3.0 \\
2.3 \\
12.4 \\
8.4 \\
5.3 \\
3.6 \\
2.3 \\
1.8 \\
2.0 \\
1.5\end{array}$ & $\begin{array}{l}18 \\
17 \\
19 \\
20 \\
18 \\
18 \\
15 \\
18 \\
14 \\
16 \\
17 \\
20\end{array}$ & $\begin{array}{l}92.3 \\
2.0 \\
1.1 \\
0.96 \\
8.7 \\
2.2 \\
1.5 \\
1.7 \\
0.4 \\
0.8 \\
1.4 \\
0.46\end{array}$ & $\begin{array}{c}169.3 \\
3.4 \\
1.9< \\
1.5< \\
29.5> \\
21.7> \\
15.2> \\
11.4> \\
9.8> \\
7.0> \\
2.5 \\
1.3\end{array}$ & $\begin{array}{r}14 \\
14 \\
9 \\
9 \\
14 \\
11 \\
10 \\
14 \\
11 \\
10 \\
14 \\
11\end{array}$ & $\begin{array}{r}133.9 \\
2.4 \\
0.8 \\
0.8 \\
17.7 \\
9.6 \\
8.6 \\
5.9 \\
6.6 \\
5.7 \\
2.3 \\
0.4\end{array}$ & \begin{tabular}{|c}
167.8 \\
4.2 \\
2.7 \\
$1.5<$ \\
15.8 \\
$10.6>$ \\
5.8 \\
4.7 \\
$2.8>$ \\
1.5 \\
3.0 \\
1.6
\end{tabular} & \begin{tabular}{l|}
9 \\
9 \\
9 \\
7 \\
9 \\
9 \\
7 \\
9 \\
8 \\
6 \\
8 \\
8
\end{tabular} & $\begin{array}{c}84.3 \\
2.2 \\
0.9 \\
0.3 \\
6.3 \\
3.1 \\
0.9 \\
1.6 \\
0.6 \\
0.3 \\
1.4 \\
0.40\end{array}$ & $\begin{array}{c}201.4 \\
4.0 \\
2.0< \\
1.4< \\
71.4> \\
39.9> \\
29.8> \\
7.9> \\
4.2> \\
3.1> \\
3.0 \\
1.4\end{array}$ & \begin{tabular}{l|}
7 \\
7 \\
7 \\
7 \\
7 \\
7 \\
7 \\
7 \\
7 \\
7 \\
7 \\
7
\end{tabular} & $\begin{array}{r}89.3 \\
2.2 \\
1.0 \\
0.8 \\
12.4 \\
12.4 \\
12.9 \\
2.1 \\
1.0 \\
1.1 \\
1.8 \\
0.3\end{array}$ \\
\hline Urine & $\begin{array}{l}\text { vol. } \\
\mathrm{Cl} \\
\mathrm{Na} \\
\mathrm{K} \\
\mathrm{N}\end{array}$ & $\begin{array}{l}\text { ml./d. } \\
\text { meq./d. } \\
\text { meq./d. } \\
\text { meq./d. } \\
\text { g./d. }\end{array}$ & $\begin{array}{r}157.3 \\
32.8 \\
30.6 \\
21.5 \\
5.2\end{array}$ & $\begin{array}{l}18 \\
18 \\
18 \\
15 \\
18\end{array}$ & $\begin{array}{r}74.6 \\
14.0 \\
16.2 \\
5.7 \\
2.1\end{array}$ & $\begin{array}{c}298.5> \\
24.3 \\
5.6< \\
14.5< \\
4.7\end{array}$ & $\begin{array}{l}14 \\
13 \\
11 \\
13 \\
13\end{array}$ & $\begin{array}{r}141.6 \\
15.4 \\
3.7 \\
11.0 \\
1.9\end{array}$ & \begin{tabular}{|r|}
193.5 \\
42.4 \\
37.8 \\
20.6 \\
5.7
\end{tabular} & $\begin{array}{l}8 \\
8 \\
8 \\
8 \\
9\end{array}$ & $\begin{array}{r}52.6 \\
6.4 \\
8.4 \\
4.3 \\
1.2\end{array}$ & $\begin{array}{c}279.7> \\
42.0 \\
109.9> \\
24.1 \\
5.2\end{array}$ & $\begin{array}{l}7 \\
7 \\
7 \\
7 \\
7\end{array}$ & $\begin{array}{r}33.2 \\
6.7 \\
17.8 \\
9.5 \\
1.4\end{array}$ \\
\hline \multicolumn{2}{|c|}{$\Delta$ Body wgt. } & $\mathrm{Kg} \cdot / \mathrm{d}$. & -0.004 & 18 & 0.033 & $-0.081<$ & 14 & 0.083 & +0.025 & 8 & 0.043 & -0.031 & 7 & 0 \\
\hline \multicolumn{2}{|c|}{$\begin{array}{l}\text { Balances: } \\
\text { External } \mathrm{Cl} \\
\text { External } \mathrm{Na} \\
\text { External K } \\
\text { External N }\end{array}$} & $\begin{array}{l}\text { meq./d. } \\
\text { meq./d. } \\
\text { meq./d. } \\
\text { g./d. }\end{array}$ & $\begin{array}{l}-0.6 \\
-5.2 \\
-2.3 \\
-0.29\end{array}$ & $\begin{array}{l}17 \\
17 \\
17 \\
16\end{array}$ & $\begin{array}{l}3.0 \\
5.4 \\
4.5 \\
0.96\end{array}$ & $\begin{array}{l}-2.2 \\
-8.4 \\
-8.2< \\
-0.91\end{array}$ & $\begin{array}{l}14 \\
14 \\
14 \\
13\end{array}$ & $\begin{array}{l}7.4 \\
7.9 \\
5.1 \\
1.44\end{array}$ & $\begin{array}{l}-1.4 \\
-1.6 \\
-0.5 \\
+0.02\end{array}$ & $\begin{array}{l}8 \\
8 \\
9 \\
8\end{array}$ & $\begin{array}{l}3.4 \\
7.2 \\
4.4 \\
0.83\end{array}$ & $\begin{array}{l}+2.4 \\
+3.7> \\
-4.1 \\
-0.18\end{array}$ & $\begin{array}{l}7 \\
7 \\
7 \\
7\end{array}$ & $\begin{array}{l}4.3 \\
8.7 \\
2.2 \\
0.49\end{array}$ \\
\hline \multicolumn{2}{|c|}{$\begin{array}{l}\text { Extracell. } \mathrm{H}_{2} \mathrm{O} \\
\text { Extracell. } \mathrm{Na} \\
\text { Extracell. } \mathrm{K}\end{array}$} & $\begin{array}{l}\text { 1./d. } \\
\text { meq./d. } \\
\text { meq./d. }\end{array}$ & $\begin{array}{l}0.00 \\
+0.3 \\
-0.1\end{array}$ & $\begin{array}{l}17 \\
15 \\
16\end{array}$ & $\begin{array}{l}0.02 \\
3.2 \\
0.3\end{array}$ & $\begin{array}{l}-0.03< \\
-4.9< \\
-0.2\end{array}$ & $\begin{array}{l}14 \\
13 \\
12\end{array}$ & $\begin{array}{l}0.05 \\
7.8 \\
0.2\end{array}$ & $\begin{array}{l}+0.01 \\
+0.5 \\
+0.2\end{array}$ & $\begin{array}{l}9 \\
9 \\
8\end{array}$ & $\begin{array}{l}0.03 \\
5.7 \\
0.3\end{array}$ & $\begin{array}{l}+0.03> \\
+4.5 \\
+0.3>\end{array}$ & $\begin{array}{l}7 \\
7 \\
6\end{array}$ & $\begin{array}{l}0.05 \\
9.0 \\
0.4\end{array}$ \\
\hline \multicolumn{2}{|l|}{$\begin{array}{l}\text { Cell. }{ }^{\mathrm{Na}} \\
\text { Cell. } \\
\text { Cell. } \\
\text { Cell. } \\
* \\
\text { K }\end{array}$} & $\begin{array}{r}\text { meq./d. } \\
\text { meq./d. } \\
\text { g./d. } \\
\text { meq./d. }\end{array}$ & $\begin{array}{l}-5.4 \\
-2.8 \\
-0.30 \\
-3.0\end{array}$ & $\begin{array}{l}16 \\
17 \\
16 \\
15\end{array}$ & $\begin{array}{l}6.5 \\
3.9 \\
0.93 \\
3.6\end{array}$ & $\begin{array}{l}-4.9 \\
-7.9< \\
-0.90 \\
-5.2\end{array}$ & $\begin{array}{l}13 \\
14 \\
13 \\
12\end{array}$ & $\begin{array}{l}7.1 \\
5.0 \\
1.44 \\
3.2\end{array}$ & $\begin{array}{c}-3.2 \\
-0.6 \\
0.00 \\
+0.7\end{array}$ & $\begin{array}{l}8 \\
9 \\
8 \\
8\end{array}$ & $\begin{array}{l}2.8 \\
4.3 \\
1.07 \\
4.7\end{array}$ & $\begin{array}{l}-0.9 \\
-4.2 \\
-0.17 \\
-3.8\end{array}$ & $\begin{array}{l}7 \\
7 \\
7 \\
7\end{array}$ & $\begin{array}{l}9.0 \\
2.0 \\
0.48 \\
1.6\end{array}$ \\
\hline
\end{tabular}

No.-Number of replicates

S. D.-Standard Deviation $-\sqrt{\frac{\text { squared sum of deviations from mean }}{\mathrm{N}-1}}$

$>$-Deviation above control mean is statistically significant ( $\mathrm{p}$ for $\mathrm{t}$-test is $<0.05$ )

$<-$ Deviation below control mean is statistically significant ( $\mathrm{p}$ for $\mathrm{t}$-test is <0.05)

* $\mathrm{K}-\mathrm{K}$ exchanges in excess of the anabolism or catabolism of $\mathrm{N}$

as does the failure to observe comparable changes following ingestion of the sodium form of the resin.

It seems clear that the action of cation exchange resins in the hydrogen cycle is analogous to the effects of administration of ammonium chloride (19, 20 ), and similar acidifying substances, with respect to production of metabolic acidosis and water diuresis. In the case of the resin, however, the renal excretion of sodium and potassium was not accelerated in contrast to the striking augmentation of their urinary outputs by so-called acidifying diuretics $(19,20)$. This failure of augmented excretion of sodium and potassium may be a reflection of increased stool output of these ions. Furthermore urinary excretion of potassium and sodium although reduced by the resin might have been even lower if acidosis had not occurred. 
Nevertheless data of the present study constitute evidence against the hypothesis that the water diuresis produced by acidifying substances is necessarily related to augmented renal excretion of sodium or potassium.

Despite the unequivocal character of the two-fold or greater rise in stool sodium during hydrogen resin therapy, and the statistically significant decreases in serum as well as extracellular sodium, the external balances of this electrolyte were not altered. This is in great measure and perhaps entirely attributable to the profound reduction in urinary sodium. This adjustment occurring regularly would obviously make it difficult if not impossible to produce salt depletion. It also suggests that even with the comparatively large doses used in these studies the resin seldom removes endogenous sodium in amounts sufficient to produce negative external balances of this cation. It should be pointed out, however, that in the diets employed in this study large amounts of sodium were ingested. No data are available to indicate whether or not depletion of endogenous sodium could be achieved by using the hydrogen form resin during regimens sharply restricted in sodium.

Similarly, as in the case of the sodium ion, the daily urinary losses of potassium declined as stool excretion of this cation rose several fold during hydrogen resin therapy. It should be emphasized, however, that in absolute terms more potassium than sodium was lost in stools during hydrogen resin ingestion. Since the diets employed and the gastrointestinal secretions contained preponderantly greater amounts of sodium than of potassium, it is obvious that the larger losses of potassium reflect the recognized greater affinity of the carboxyl cation exchangers for this element over sodium. The large increase in stool potassium during resin therapy, together with a proportionately smaller decrease in the concomitant urinary losses of potassium, resulted in negative balances of body potassium. The losses represented decreases in cell potassium, since extracellular potassium did not change. The accompanying deficits of cell nitrogen were of insufficient magnitude to account for all of the potassium lost from cells. It is clear, therefore, that potassium was lost in these experiments both with and in excess of the catabolism of cell protein. This was not accompanied, presumably because the experimental periods were short, by any of the usual clinical indices of potassium depletion.

It has been previously noted in studies from this and other laboratories that such negative balances of potassium may be associated with an apparent entry of sodium into the cell $(12,14,15)$. The mean daily change in cell sodium, however, cannot be established as statistically different from the control values. It has already been pointed out earlier that in our studies with the hydrogen form of the resin cell potassium deficits developed during a metabolic acidosis, a state which may result in transfers of sodium out of cells (21-23). These stimuli toward divergent movements of this ion may therefore have cancelled one another.

Finally it is evident that although administering the resin in the sodium cycle does raise stool potassium without concomitant acidosis, these increments are of lesser magnitude than those produced by the hydrogen resin and are not accompanied by decreases in serum potassium concentration, nor in the mean daily urinary potassium excretion. Potassium balances remain unaffected. It should be reiterated that use of this particular form of the exchanger results in considerable absorption and retention of the released sodium. This latter development results in positive balances of the electrolyte and expansion of the volume of the extracellular fluid as measured by the chloride space.

\section{SUMMARY AND CONCLUSIONS}

1. Administration of a hydrogen cycle carboxylic cation exchange resin to dogs, 30 to $60 \mathrm{~g}$./day for seven to 11 days, produced a statistically significant decrease in serum sodium, a rise in serum chloride and a metabolic acidosis characterized by a fall in serum carbon dioxide content and $\mathrm{pH}$.

2. During therapy with this resin, increased amounts of sodium and of potassium were lost in stools without alteration in stool chloride or nitrogen excretion.

3 . With hydrogen resin ingestion urine volumes rose with a decrease in urinary concentrations of sodium, potassium, chloride and nitrogen; the daily output of sodium and of potassium fell si- 
multaneously with the increased losses in stools.

4. Hydrogen cycle resin administration lowered the total amount of sodium in the chloride space without producing any statistically detectable change in the external balances of this cation.

5. Negative external and cell balances of potassium increased significantly during hydrogen resin therapy. These were related in part to the particular affinity of the resin for potassium and in part to a less than completely compensatory decrease in the urinary excretion of this element.

6. Administration of the same carboxylic cation exchanger in the sodium rather than the hydrogen form resulted in an extracellular retention of some of the released sodium despite increased losses of this ion in stools and in urine.

7. During sodium cycle resin therapy a statistically significant increase in the stool losses of potassium occurred, smaller in magnitude, however, than that observed with the hydrogen cycle exchanger and unaccompanied by any detectable change in the daily urinary output or in the daily balance of potassium.

8. In contrast to the hydrogen form of the exchanger administration of the sodium charged resin did not result in an acidosis but did produce a decrease rather than an increase in serum chloride, possibly as a manifestation of the increased urinary sodium losses.

\section{REFERENCES}

1. Dock, W., Sodium depletion as a therapeutic procedure: the value of ion-exchange resins in withdrawing sodium from the body. Tr. A. Am. Physicians, 1946, 59, 282.

2. Ch'en, J. S., and Freeman, S., The removal of cations from solutions and the rat's alimentary canal by H-form resins. J. Lab. \& Clin. Med., 1950, 35, 99.

3. McChesney, E. W., and McAuliff, J. P., Effects of some ion exchange resins on the mineral metabolism of rats. Am. J. Physiol., 1950, 160, 264.

4. Danowski, T. S., Greenman, L., Peters, J. H., and Mateer, F. M., An introduction to experimental and clinical studies of carboxylic cation exchange resin. J. Clin. Invest., 1951, 30, 979.

5. Danowski, T. S., Peters, J. H., Rathbun, J. C., Quashnock, J. M., and Greenman, L., Studies in diabetic acidosis and coma, with particular emphasis on the retention of administered potassium. J. Clin. Invest., 1949, 28, 1.
6. Greenman, L., Mateer, F. M., Gow, R. C., Peters, J. H., and Danowski, T. S., Some observations on the development of hypokaliemia during therapy of diabetic acidosis in juvenile and young adult subjects. J. Clin. Invest., 1949, 28, 409.

7. Danowski, T. S., and Gilmore, G. H., Relationships between serum water or weight and protein concentration. J. Lab. \& Clin. Med., 1950, 35, 67.

8. Wallace, W. M., Improved flame photometer for sodium and potassium analyses. Am. J. Dis. Child., 1949, 77, 104.

9. Wallace, W. M., Holliday, M., Cushman, M., and Elkinton, J. R., The application of the internal standard flame photometer to the analysis of biological material. J. Lab. \& Clin. Med., 1951, 37, 621.

10. Mateer, F., Greenman, L., Peters, J. H., Weigand, F. A., and Danowski, T. S., Stool electrolyte and nitrogen output during various dietary regimens. Unpublished.

11. Elkinton, J. R., and Taffel, M., Prolonged water deprivation in the dog. J. Clin. Invest., 1942, 21, 787.

12. Elkinton, J. R., and Winkler, A. W., Transfers of intracellular potassium in experimental dehydration. J. Clin. Invest., 1944, 23, 93.

13. Elkinton, J. R., Winkler, A. W., and Danowski, T. S., Inactive cell base and the measurement of changes in cell water. Yale J. Biol. \& Med., 1944, 17, 383.

14. Darrow, D. C., The retention of electrolytes during recovery from severe dehydration due to diarrhea. J. Pediat., 1946, 28, 515.

15. Elkinton, J. R., Winkler, A. W., and Danowski, T. S., Transfers of cell sodium and potassium in experimental and clinical conditions. J. Clin. Invest., 1948, 27, 74.

16. Danowski, T. S., Greenman, L., Gow, R. C., Weigand, F. W., Mateer, F. M., Peters, J. H., Cosgrove, E. F., Seiferth, W., and Davis, N., Electrolyte and nitrogen balance studies in patients receiving a nitrogen mustard. J. Pharmacol. \& Exper. Therap., 1950, 98, 147.

17. Danowski, T. S., Austin, A. C., Gow, R. C., Mateer, F. M., Weigand, F. A., Peters, J. H., and Greenman, L., Electrolyte and nitrogen balance studies in infants following cessation of vomiting. Pediatrics, 1950, 5, 57.

18. Snedecor, G. W., Statistical Methods Applied to Experiments in Agriculture and Biology. Collegiate Press, Ames, Iowa, 1937.

19. Gamble, J. L., Blackfan, K. D., and Hamilton, B., A study of the diuretic action of acid producing salts. J. Clin. Invest., 1925, 1, 359.

20. Loeb, R. F., Atchley, D. W., Richards, D. W., Jr., Benedict, E. M., and Driscoll, M. E., On the mechanism of nephrotic edema. J. Clin. Invest., 1932, 11, 621.

21. Darrow, D. C., Schwartz, R., Iannucci, J. F., and Coville, F., The relation of serum bicarbonate con- 
centration to muscle composition. J. Clin. Invest., 1948, 27, 198.

22. Danowski, T. S., Newer concepts of the role of sodium in disease. Am. J. Med., 1951, 10, 468.

23. Danowski, T. S., and Elkinton, J. R., Exchanges of potassium related to organs and systems. Pharmacol. Rev., 1951, 3, 42.

\section{ADDENDUM}

The data were calculated in the following manner:

I. External Balance: $\mathrm{b}=\mathrm{I}-\mathrm{O}$ where $\mathrm{b}=$ external balance; $\mathrm{I}=$ intake; and $\mathrm{O}=$ total output including the amounts of the substance in urine, stool, vomitus and in the serum contained in the blood withdrawn.

II. In order to apportion the external balance between cells and extracellular fluid, the amount in the extracellular fluid was calculated and then subtracted from the external balance.

A. Conversion of serum values of electrolytes into concentrations in extracellular water employing corrections for Donnan effect and for water content of serum.

$$
\begin{gathered}
\frac{[\mathrm{Cl}]_{\mathrm{B}}}{(0.95)\left[\mathrm{H}_{2} \mathrm{O}\right]_{\mathrm{B}}}=[\mathrm{Cl}]_{\mathrm{ECW}} \\
\frac{[\mathrm{Na}]_{\mathrm{g}} \times(0.95)}{\left[\mathrm{H}_{2} \mathrm{O}\right]_{\mathrm{g}}}=[\mathrm{Na}]_{\mathrm{ECW}} \\
\frac{[\mathrm{K}]_{\mathrm{g}} \times(0.95)}{\left[\mathrm{H}_{2} \mathrm{O}\right]_{\mathrm{g}}}=[\mathrm{K}]_{\mathrm{ECW}}
\end{gathered}
$$

where []$_{0}=$ serum concentration in meq. $/ 1$.

0.95 = correction for Donnan effect

$\left[\mathrm{H}_{2} \mathrm{O}\right]_{\mathrm{g}}=$ water concentration of serum in $\mathrm{Kg} . / 1$.

B. Calculation of extracellular wa ter changes were based on the chloride space, assuming that chloride was confined to this compartment, and that the initial extracellular fluid made up $20 \%$ of the body weight in a normally hydrated subject.

$[\mathrm{Cl}]_{\mathrm{ECW}} \times(\mathrm{ECW})_{1}+\mathrm{bCl}=[\mathrm{Cl}]_{\mathrm{ECW}} \times(\mathrm{ECW})_{2}$

Rearranging:

$$
(\mathrm{ECW})_{2}=\frac{[\mathrm{Cl}]_{\mathrm{ECW}_{2}} \times(\mathrm{ECW})_{1}+\mathrm{bCl}}{[\mathrm{Cl}]_{\mathrm{ECW}}}
$$

where $[\mathrm{Cl}]_{\mathrm{ECW}}=$ chloride concentration in meq./1. in extracellular fluid at start of period

$[\mathrm{Cl}]_{\mathrm{ECW}}=$ chloride concentration in meq./1. in extracellular fluid at end of period

$(\mathrm{ECW})_{1}=$ assumed extracellular volume at start obtained by multiplying body weight in kilograms by 0.20

$(\mathrm{ECW})_{2}=\underset{\text { at end }}{\text { unknown extracellular volume }}$

$\mathrm{bCl}=$ external balance of $\mathrm{Cl}$ in the period

C. Changes in extracellular $\mathrm{Na}$ and $\mathrm{K}$ represent the difference between final and initial amounts of these substances in this compartment.

$$
\begin{aligned}
& {[\mathrm{Na}]_{\mathrm{ECW}} \times(\mathrm{ECW})_{2}-[\mathrm{Na}]_{\mathrm{ECW}} \times(\mathrm{ECW})_{1}} \\
& =\Delta \mathrm{NaECW} \\
& {[\mathrm{K}]_{\mathrm{ECW}} \times(\mathrm{ECW})_{2}-[\mathrm{K}]_{\mathrm{ECW}} \times(\mathrm{ECW})_{1}} \\
& =\Delta K_{\text {EOW }}
\end{aligned}
$$

D. Cellular balances indicate the difference between the external and the extracellular balance.

$$
\begin{aligned}
& \text { b Na }-\Delta \mathrm{Na}_{\mathrm{EOW}}=\Delta \text { Naicw } \\
& \text { b } \mathrm{K}-\Delta \mathrm{K}_{\mathrm{EOW}}=\Delta \mathrm{K}_{\mathrm{IOW}}
\end{aligned}
$$

where $\mathbf{b}=$ external balance

$$
\Delta_{\mathrm{ECW}}=\text { extracellular balance }
$$$$
\Delta_{\mathrm{ICW}}=\text { intracellular balance }
$$

E. Determination of the intracellular balance of potassium which is in excess of the amount associated with nitrogen requires correction of this balance for the amount associated with nitrogen metabolism. Since $2.38 \mathrm{meq}$. of $\mathrm{K}$ are associated with each gram of intracellular nitrogen this is simply calculated. Nitrogen balances, however, must be corrected for NPN changes since these obviously alter the observed external balance. For example assuming that the NPN is distributed throughout total body water, and the body water comprises $65 \%$ of the body weight the following formulae are applicable:

$$
\begin{gathered}
\frac{\text { (Body wgt.)(0.65) } \times \Delta N P N \times 10}{1000}=b \text { NPN } \\
\text { b N }- \text { b NPN }=b^{\prime} N
\end{gathered}
$$

where $\triangle N P N=$ change in NPN in mgm. \% (with sign)

b NPN = change in $N$ balance associated with change in NPN

b $\mathrm{N}=$ external balance of $\mathrm{N}$

$b^{\prime} \mathbf{N}=$ balance of $N$ corrected for $N P N$ change

The importance of this correction is illustrated: if we have a $60 \mathrm{Kg}$. subject whose NPN changes from $40 \mathrm{mgm}$. \% to $30 \mathrm{mgm}$. \%, the correction will be as large as $-3.9 \mathrm{~g}$. of $\mathrm{N}$. If the NPN in this person went from 30 to 50 , then the $b$ NPN would equal $+7.8 \mathrm{~g}$. N. This will, of course, significantly alter the external balance of $\mathrm{N}$.

In order to determine the intracellular $K$ balance which does not represent $K$. moving with protein metabolism the following calculations must be performed:

$$
\left(\mathrm{b}^{\prime} \mathrm{N}\right) \times(2.38)=\mathrm{K}_{\mathrm{N}}
$$

where $\mathrm{K}_{\mathrm{N}}=\mathrm{K}$ associated with protein metabolism

$$
\Delta \mathrm{K}_{\mathrm{ICW}}-\mathrm{K}_{\mathrm{N}}=\Delta \mathrm{K}_{\mathrm{ICW}}
$$

where $\Delta K^{\prime}$ Iow $=$ change in intracellular $K$ in excess of the $K$ associated with $N$ metabolism

The amounts of $\mathrm{Na}$ associated with $\mathrm{N}$ metabolism are so small that this correction may be omitted. 